\title{
RENAL EXCRETION AT LOW URINE VOLUMES AND THE MECHANISM OF OLIGURIA
}

\author{
By LEON C. CHESLEY \\ (From the Department of Biochemistry, Margaret Hague Maternity Hospital, Jersey City)
}

(Received for publication April 5, 1938)

In previous papers $(1,2)$ it was shown that when the urine volume output falls below about $0.35 \mathrm{ml}$. per minute, the urine becomes "maximally" concentrated with respect to urea. The urea concentration of the urine is constant below this critical volume, and thus the urea clearance ( $\mathrm{U} V / B)$ varies directly and quantitatively with the urine volume $(\mathrm{V})$.

In an effort to analyze the mechanism of renal excretion at low urine volumes, the plasma clearance of endogenous creatinine, and the excretions of phosphorus, total nitrogen, and total solids have been studied in a series of oliguric subjects. These findings are the basis for this report.

\section{MATERIAL AND METHODS}

Series of excretion studies were carried out, using four normal non-pregnant adults, one normal pregnant woman at term, six patients with preeclamptic toxemia, one patient with terminal malignant nephrosclerosis and cardiac decompensation, one with Bright's disease, and one unclassified cardiac patient. In the normals, a thirty to sixty hour food and water fast was necessary to get the urine volume down to the desired level. In the toxemia patients, a twelve hour fast sufficed, while the patient with renal disease required no preparation. Most of the urines were taken at hourly intervals, though some were for longer periods up to three hours. When the completeness of collection was controlled by washing out the bladder, specimens were taken at intervals of twenty to thirty minutes. In the first two normals, voided specimens were used; in all other cases the urines were obtained by catheter. In the later experiments the urine was first collected, and then the bladder washed out twice with saline at the end of each collection. The washings were separately analyzed. The observed urine volume was corrected by adding the volume of urine calculated, from the creatinine, to be in the saline washings.

The apparent plasma creatinine was determined in a modified Folin-Wu filtrate of the plasma, by the method of Folin and Wu (3). Urinary creatinine was determined by Folin's (3) method.

For the determination of urinary nitrogen, $1 \mathrm{ml}$. of urine was diluted to volume in a $200 \mathrm{ml}$. volumetric flask. From this were taken 2, 3, and $5 \mathrm{ml}$. samples which were digested by the Wong persulphate method
(4). After cooling, they were nesslerized and read against a standard containing 0.15 or $0.25 \mathrm{mgm}$. of nitrogen. Correction was made for protein whenever present.

Inorganic phosphorus was determined in 1, 2, and 5 ml. samples of the urine diluted 1:200. Youngburg's method (3) was used.

Total solids were determined indirectly, because of the small amounts of urine available. Using calibrated pipettes, 10 , or when necessary, $5 \mathrm{ml}$. of urine were weighed to a tenth of a milligram. The specific gravity was then calculated and corrected for protein (for each 10 grams of protein per liter 0.0030 was subtracted from the specific gravity). The significant figures in the specific gravity were then multiplied by Long's coefficient, 2.6, to get the approximate total solid content (3).

All data were fitted to curves derived by the method of least squares.

\section{RESULTS}

As was previously reported for the excretion of urea, all substances investigated are maximally concentrated when the urine volume falls to 0.35 to $0.50 \mathrm{ml}$. per minute. Further decrease in volume is without effect upon the concentration of creatinine, phosphorus, total nitrogen, total solids, or total non-nitrogenous solids. Like urea, their excretion at low urine volumes depends linearly and quantitatively upon the volume.

The influence of the urine volume upon the plasma clearance of endogenous creatinine is shown in Figure 1. In all cases, when the clearances are plotted against the urine volume, the best fitting curve for the data is a straight line originating close to zero on the coordinates. The mean curve shown was derived by averaging the equations obtained for the different series of clearances. The ratio of each line to the mean line was then calculated. Each point on each line was then multiplied by the appropriate factor and plotted with reference to the mean curve. This is a simple method of averaging all observations to determine their trend and distribution. The actually observed data are summarized in Table I which also gives the individual equations best describing the data. 
TABLE I

Plasma clearances of endogenous creatinine at low urine volumes

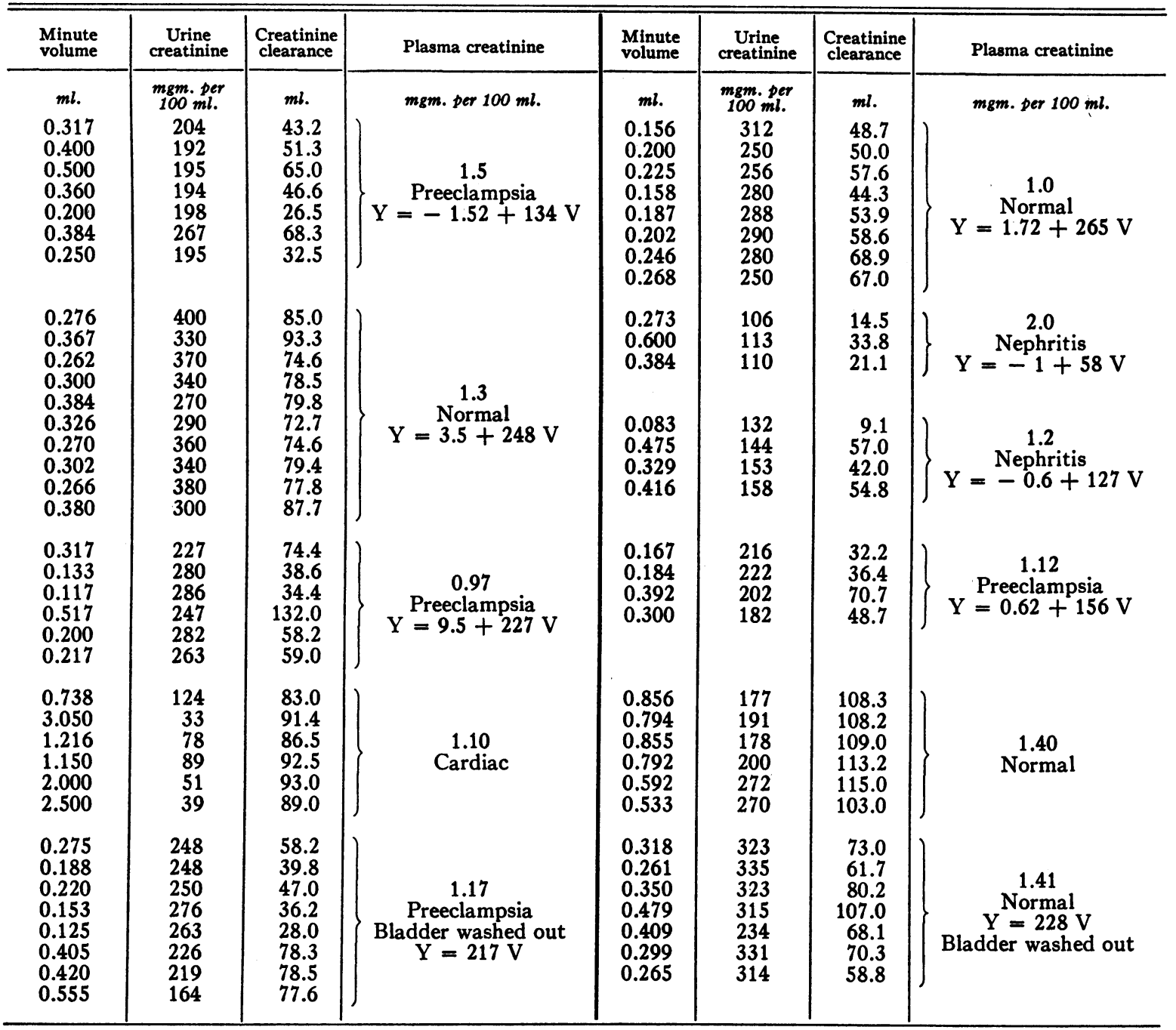

Since the endogenous creatinine clearance has been interpreted as a measure of glomerular filtration in the human kidney (5), these results carry an important theoretical significance. In the first experiments, the creatinine clearances were done with catheterized specimens, but the bladder was not washed out. This leaves the possibility that the actual urine volume output may have been constant while varying quantities of the urine were left in the bladder folds. To rule out this possibility, later urine collections were made quantitative by washing out the bladder at each period, as described above. The results of these creatinine clearances accorded with those in the earlier cases. In Figure 1, the results of the wash-out experiments are shown by the symbol $\mathrm{X}$ which follows the straight line as closely as do the other symbols. In the pregnant patients possible retention of urine in the ureters must be considered. However, the results agree for all subjects, pregnant or not, normal or not, and with bladder washed out or not. The results for the minute excretion ( $\mathrm{U} \mathrm{V}$ ) of inorganic phosphorus, total nitrogen, total solids, and total non-nitrogenous solids are shown in Figures 2, 3, and 4. The data were averaged for graphing in the same manner as described for the creatinine clearances. In all cases, straight lines extrapolating back to 
zero origin best describe the trend of the excretions when the excretion is plotted against the urine volume. Table II presents these data. As was the case for both urea and creatinine clear-

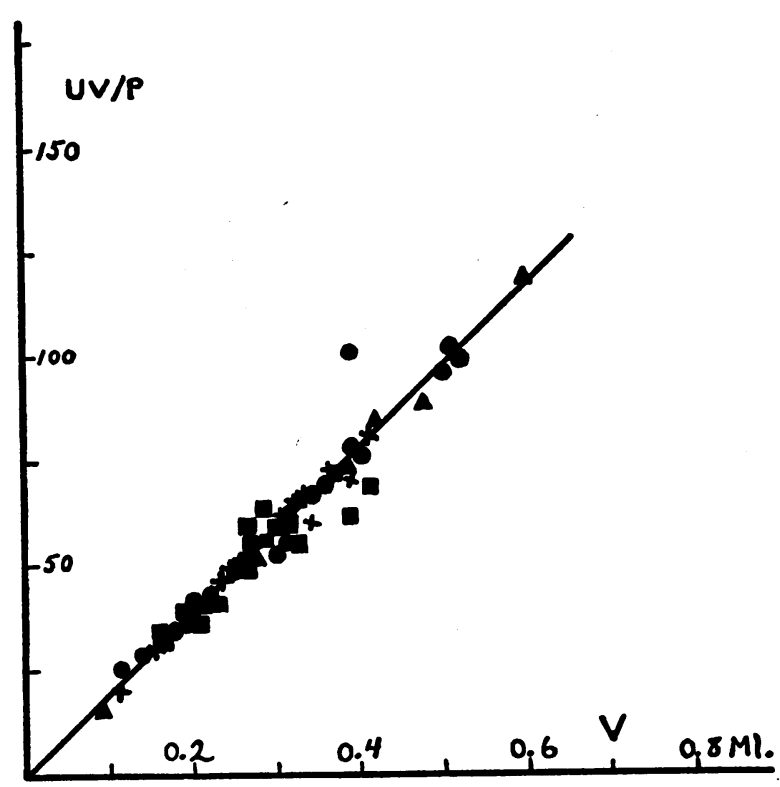

Fig. 1. Plasma Clearances of Endogenous Creatinine at Low Urine Volumes

- Normal subjects

- Preeclamptic patients

- Nephritic patients

$\times$ Data from urine collections made quantitative by washing out bladder.

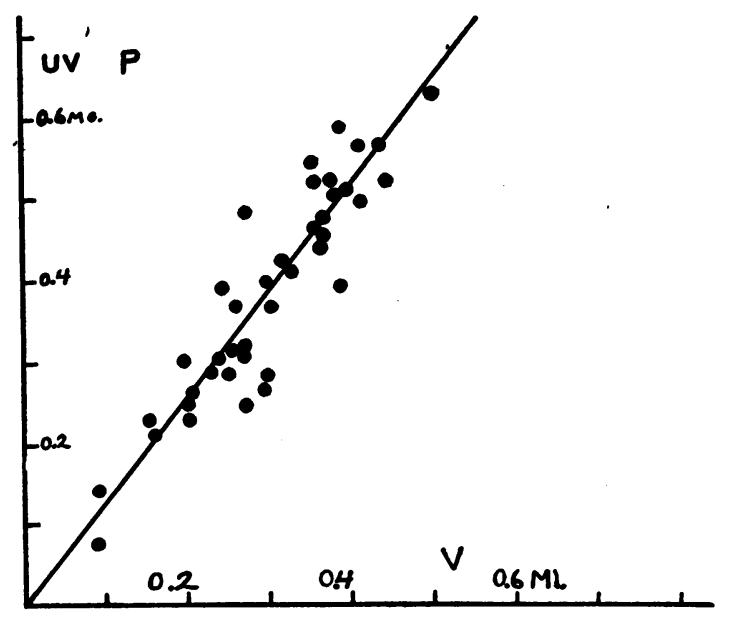

Fig. 2. Inorganic Phosphorus Excretion at Low Urine Volumes. All Results, from Normal, Preeclamptic, and Nephritic Subjects Averaged and Plotted with Reference to Mean Curve, as Described IN TEXT. ances at minimal volumes, the excretion of inorganic phosphorus, total nitrogen, and total solids depends linearly and quantitatively upon the urine volume. The same is true of the non-nitrogenous solids, obtained by subtracting total nitrogen from total solids in cases where parallel determinations were made. Here the nitrogenous solids were calculated approximately, as urea, by multiplying the total nitrogen by 2.15 .

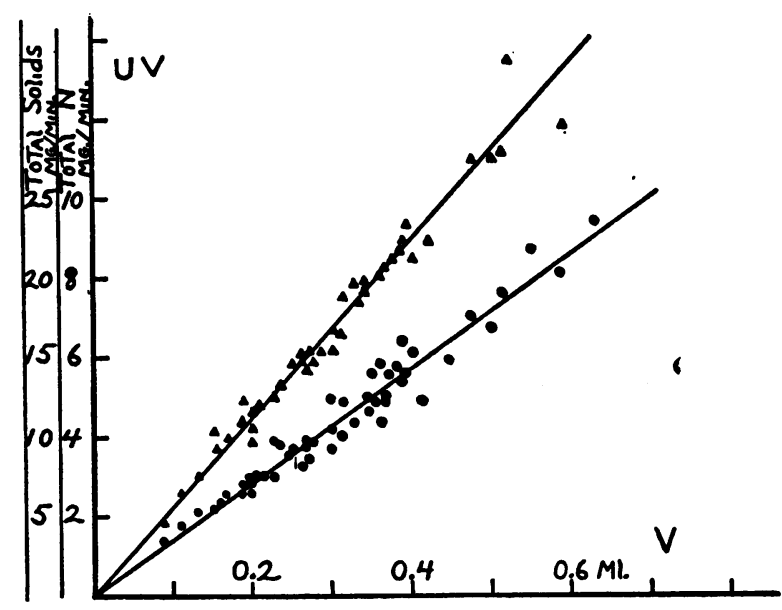

Fig. 3. Total Solid and Total Nitrogen Excretion at Low URINe Volumes

Total solids

- Total nitrogen.

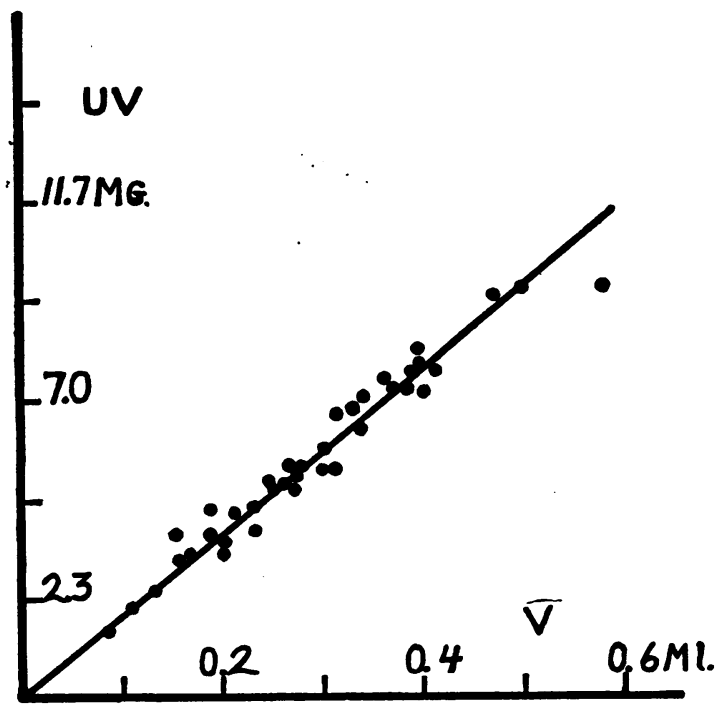

Fig. 4. The Excretion (U V) of Total Non-Nitrogenous Solids at Low Urine Volumes; Data Obtained by Subtracting (Total Nitrogen $\times 2.15$ ) From Total Solids. 


\section{DISCUSSION}

Miller and Dubos (6) have recently compared the Jaffe reaction, the new dinitrobenzoic acid colorimetric method, and a specific enzyme method in studying the plasma and whole blood creatinine. They found that for plasma creatinine the values obtained by the three methods agreed very well. Since the enzyme used is specific for creatinine, they concluded that the Jaffe reaction does measure fairly accurately the true creatinine level of the plasma. Using this specific enzyme method,
Miller and Winkler (5) found that the plasma clearance of endogenous creatinine was usually, though not always, equal to the inulin clearance. Immediately following the injection of exogenous creatinine, these workers found an abrupt rise in the creatinine clearance while the inulin clearance remained unchanged. They suggested that the increased clearance of creatinine might be attributed to a tubular secretion which had been absent until the stimulus of the increased plasma level came into being. This might also mean that all

TABLE II

The excretion of inorganic phosphorus, total nitrogen, and total solids at low urine volumes

\begin{tabular}{|c|c|c|c|c|c|c|c|}
\hline $\begin{array}{l}\text { Minute } \\
\text { volume }\end{array}$ & Phosphorus & $\begin{array}{c}\text { Phosphorus } \\
\text { excretion }\end{array}$ & Total nitrogen & $\begin{array}{l}\text { Nitrogen } \\
\text { excretion }\end{array}$ & $\begin{array}{l}\text { Total } \\
\text { solids }\end{array}$ & $\begin{array}{c}\text { Solid } \\
\text { excretion }\end{array}$ & Subject and equations \\
\hline$m l$. & $\begin{array}{c}\text { mgm. per } \\
m i .\end{array}$ & $\begin{array}{c}\text { mgm. per } \\
\text { minute }\end{array}$ & mgm. per ml. & $\underset{\text { minute }}{\operatorname{mgm} . \text { per }}$ & $\begin{array}{c}\text { mgm. per } \\
\text { mi. }\end{array}$ & $\begin{array}{c}\text { mgm. per } \\
\text { minute }\end{array}$ & \\
\hline $\begin{array}{l}0.317 \\
0.400 \\
0.500 \\
0.360 \\
0.200 \\
0.384 \\
0.250\end{array}$ & $\begin{array}{l}0.814 \\
0.846 \\
0.760 \\
0.732 \\
0.755 \\
0.800 \\
0.767\end{array}$ & $\begin{array}{l}0.258 \\
0.338 \\
0.380 \\
0.263 \\
0.151 \\
0.307 \\
0.192\end{array}$ & $\begin{array}{l}5.08 \\
5.04 \\
4.45 \\
3.84 \\
4.00 \\
5.56 \\
4.88\end{array}$ & $\begin{array}{l}1.61 \\
2.02 \\
2.22 \\
1.38 \\
0.80 \\
2.13 \\
1.22\end{array}$ & $\begin{array}{l}37.4 \\
33.6 \\
35.2 \\
36.7 \\
30.7 \\
37.0 \\
37.0\end{array}$ & $\begin{array}{r}11.82 \\
13.43 \\
17.58 \\
13.20 \\
6.14 \\
14.20 \\
9.25\end{array}$ & $\begin{array}{l}\text { Preeclampsia * } \\
\text { Phosphorus excreted } \\
=78.4 \times \text { Volume } \\
\text { Nitrogen excreted } \\
=47.3 \times \text { Volume } \\
\text { Solids excreted } \\
\quad=357 \times \text { Volume }\end{array}$ \\
\hline $\begin{array}{l}0.417 \\
0.350 \\
0.550 \\
0.367 \\
0.584 \\
0.367 \\
0.633 \\
0.443\end{array}$ & $\begin{array}{l}0.727 \\
0.917 \\
0.833 \\
0.858 \\
0.800 \\
0.788 \\
0.816 \\
0.714\end{array}$ & $\begin{array}{l}0.304 \\
0.321 \\
0.457 \\
0.314 \\
0.466 \\
0.289 \\
0.516 \\
0.315\end{array}$ & $\begin{array}{r}7.35 \\
10.08 \\
10.00 \\
8.35 \\
8.74 \\
9.60 \\
9.32 \\
8.20\end{array}$ & $\begin{array}{l}3.06 \\
3.53 \\
5.50 \\
3.06 \\
5.08 \\
3.52 \\
\mathbf{5 . 9 0} \\
\mathbf{3 . 6 3}\end{array}$ & & & $\begin{array}{l}\text { Preeclampsia } \\
\text { Phosphorus excreted } \\
\quad=80.4 \times \text { Volume } \\
\text { Nitrogen excreted } \\
\quad=89.8 \times \text { Volume }\end{array}$ \\
\hline $\begin{array}{l}0.355 \\
0.360 \\
0.237 \\
0.348\end{array}$ & $\begin{array}{l}1.023 \\
1.063 \\
1.203 \\
1.249\end{array}$ & $\begin{array}{l}0.364 \\
0.383 \\
0.286 \\
\mathbf{0 . 4 3 5}\end{array}$ & $\begin{array}{l}13.62 \\
16.22 \\
16.48 \\
13.31\end{array}$ & $\begin{array}{l}4.84 \\
5.85 \\
3.91 \\
4.64\end{array}$ & $\begin{array}{l}\text { Nitrogen } \\
=142 \times\end{array}$ & $\begin{array}{l}\text { veretion } \\
\text { Volume }\end{array}$ & $\left\{\begin{array}{l}\text { Unclassified cardiac } \\
\text { patient } \\
\text { Phosphorus excretion } \\
=104.8 \times \text { Volume }\end{array}\right.$ \\
\hline $\begin{array}{l}0.167 \\
0.184 \\
0.392 \\
0.300 \\
0.234\end{array}$ & & ' & $\begin{array}{r}12.28 \\
11.02 \\
10.84 \\
9.45 \\
12.72\end{array}$ & $\begin{array}{l}2.05 \\
2.03 \\
4.25 \\
2.83 \\
2.98\end{array}$ & $\begin{array}{l}60.8 \\
59.6 \\
60.8 \\
53.0 \\
52.7\end{array}$ & $\begin{array}{l}10.15 \\
10.98 \\
23.86 \\
15.90 \\
12.30\end{array}$ & $\left\{\begin{array}{l}\text { Preeclampsia * } \\
\text { Nitrogen excreted } \\
=111 \times \text { Volume } \\
\text { Solids excreted } \\
=572 \times \text { Volume }\end{array}\right.$ \\
\hline $\begin{array}{l}0.156 \\
0.200 \\
0.225 \\
0.158 \\
0.187 \\
0.202 \\
0.246 \\
0.268\end{array}$ & & & $\begin{array}{l}16.95 \\
16.22 \\
16.12 \\
16.40 \\
18.28 \\
17.26 \\
17.84 \\
17.72\end{array}$ & $\begin{array}{l}2.64 \\
3.24 \\
3.63 \\
2.59 \\
3.41 \\
3.49 \\
4.38 \\
4.75\end{array}$ & $\begin{array}{l}69.7 \\
55.0 \\
58.0 \\
61.2 \\
69.7 \\
64.2 \\
62.2 \\
59.8\end{array}$ & $\begin{array}{r}10.88 \\
11.00 \\
13.05 \\
9.68 \\
13.03 \\
12.97 \\
15.30 \\
16.00\end{array}$ & $\begin{array}{l}\text { Normal * } \\
\text { Nitrogen excreted } \\
=172 \times \text { Volume } \\
\text { Solids excreted } \\
\quad=584 \times \text { Volume }\end{array}$ \\
\hline $\begin{array}{l}0.276 \\
0.367 \\
0.262 \\
0.300 \\
0.384 \\
0.326 \\
0.270 \\
0.302 \\
0.266 \\
0.380\end{array}$ & & & $\begin{array}{l}20.40 \\
21.44 \\
20.00 \\
22.70 \\
22.42 \\
24.40 \\
23.08 \\
27.00 \\
22.77 \\
24.50\end{array}$ & $\begin{array}{l}\mathbf{5 . 6 3} \\
7.87 \\
\mathbf{5 . 2 4} \\
\mathbf{6 . 8 1} \\
\mathbf{8 . 6 2} \\
7.96 \\
\mathbf{6 . 2 3} \\
\mathbf{8 . 1 5} \\
\mathbf{6 . 0 5} \\
\mathbf{9 . 3 1}\end{array}$ & $\begin{array}{l}80.0 \\
83.6 \\
86.8 \\
83.6 \\
85.8 \\
91.0 \\
82.4 \\
82.5 \\
82.5 \\
84.5\end{array}$ & $\begin{array}{l}22.10 \\
30.70 \\
22.70 \\
25.10 \\
32.95 \\
29.62 \\
22.20 \\
24.90 \\
21.95 \\
32.10\end{array}$ & $\begin{array}{l}\text { Normal * } \\
\text { Nitrogen excreted } \\
\quad=231 \times \text { Volume } \\
\text { Solids excreted } \\
\quad=845 \times \text { Volume }\end{array}$ \\
\hline
\end{tabular}


TABLE II-Continued

\begin{tabular}{|c|c|c|c|c|c|c|c|}
\hline $\begin{array}{l}\text { Minute } \\
\text { volume }\end{array}$ & Phosphorus & $\mid \begin{array}{l}\text { Phosphorus } \\
\text { excretion }\end{array}$ & Total nitrogen & $\begin{array}{c}\text { Nitrogen } \\
\text { excretion }\end{array}$ & $\begin{array}{l}\text { Total } \\
\text { solids }\end{array}$ & $\begin{array}{c}\text { Solid } \\
\text { excretion }\end{array}$ & Subject and equations \\
\hline $\begin{array}{c}m l . \\
0.317 \\
0.200 \\
0.133 \\
0.117 \\
0.217 \\
0.517\end{array}$ & $\underset{m l .}{m g m .}$ & $\underset{\substack{\text { minuste } \\
\text { mim. per }}}{\text { per }}$ & $\begin{array}{c}\text { mgm. per ml. } \\
10.28 \\
12.44 \\
12.90 \\
12.50 \\
11.72 \\
11.26\end{array}$ & $\begin{array}{c}\substack{m g m . ~ p e r \\
\text { minuter }} \\
3.26 \\
2.48 \\
1.72 \\
1.46 \\
2.54 \\
5.83\end{array}$ & $\begin{array}{c}\underset{m g m .}{\text { mi. }} \text { per } \\
67.6 \\
66.4 \\
63.8 \\
63.3 \\
61.4\end{array}$ & 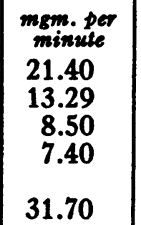 & $\begin{array}{l}\text { Preeclampsia * } \\
\text { Nitrogen excreted } \\
=116 \times \text { Volume } \\
\text { Solids excreted } \\
=640 \times \text { Volume }\end{array}$ \\
\hline \multirow[t]{2}{*}{$\begin{array}{l}0.083 \\
0.475 \\
0.329 \\
0.416\end{array}$} & & & $\begin{array}{l}6.68 \\
6.60 \\
5.85 \\
6.31\end{array}$ & $\begin{array}{l}0.55 \\
3.14 \\
1.92 \\
2.62\end{array}$ & $\begin{array}{l}33.8 \\
36.4 \\
36.4 \\
33.8\end{array}$ & $\begin{array}{r}2.80 \\
17.30 \\
11.95 \\
14.03\end{array}$ & $\begin{array}{l}\text { Preeclampsia } \\
\text { Nitrogen excreted } \\
\quad=63.2 \times \text { Volume } \\
\text { Solids excreted } \\
\quad=354 \times \text { Volume }\end{array}$ \\
\hline & & & & $\begin{array}{c}\text { Minute } \\
\text { volume }\end{array}$ & Phosphorus & $\begin{array}{l}\text { Phosphorus } \\
\text { excretion }\end{array}$ & \\
\hline $\begin{array}{l}0.276 \\
0.367 \\
0.262 \\
0.300 \\
0.384 \\
0.326 \\
0.270 \\
0.302 \\
0.266 \\
0.380\end{array}$ & $\begin{array}{l}2.56 \\
2.08 \\
2.06 \\
1.79 \\
1.87 \\
1.82 \\
1.33 \\
1.37 \\
1.74 \\
2.28\end{array}$ & $\begin{array}{l}0.706 \\
0.764 \\
0.540 \\
0.538 \\
0.718 \\
0.594 \\
0.359 \\
0.413 \\
0.464 \\
0.866\end{array}$ & $\left\{\begin{array}{l}\text { Normal } \\
\text { Phosphorus excreted } \\
\quad=250 \times \text { Volume } \\
-0.19\end{array}\right.$ & $\begin{array}{l}m l . \\
0.156 \\
0.200 \\
0.225 \\
0.158 \\
0.187 \\
0.202 \\
0.246 \\
0.268\end{array}$ & $\begin{array}{c}\underset{\text { mgm. per }}{\text { ml. }} \\
1.74 \\
1.36 \\
1.46 \\
1.57 \\
1.90 \\
1.47 \\
1.33 \\
1.37\end{array}$ & $\begin{array}{c}\begin{array}{c}\text { mgm. per } \\
\text { minute }\end{array} \\
0.272 \\
0.272 \\
0.328 \\
0.248 \\
0.356 \\
0.297 \\
0.327 \\
0.367\end{array}$ & $\left\{\begin{array}{l}\text { Normal } \\
\text { Phosphorus excreted } \\
=0.116+93.5 \\
\times \text { Volume }\end{array}\right.$ \\
\hline $\begin{array}{l}0.533 \\
0.478 \\
0.856 \\
0.792 \\
0.592\end{array}$ & $\begin{array}{l}1.274 \\
1.709 \\
0.800 \\
0.952 \\
1.235\end{array}$ & $\begin{array}{l}0.682 \\
0.816 \\
0.685 \\
0.753 \\
0.730\end{array}$ & $\begin{array}{l}\text { Normal } \\
\text { Phosphorus excreted } \\
\text { (no equation) }\end{array}$ & $\begin{array}{l}0.657 \\
0.284 \\
0.241 \\
0.318 \\
0.464 \\
1.294\end{array}$ & $\begin{array}{l}0.390 \\
0.576 \\
0.588 \\
0.719 \\
0.494 \\
0.200\end{array}$ & $\begin{array}{l}0.256 \\
0.163 \\
0.142 \\
0.228 \\
0.229 \\
0.258\end{array}$ & Normal \\
\hline $\begin{array}{l}0.083 \\
0.238 \\
0.292 \\
0.297 \\
0.092\end{array}$ & $\begin{array}{l}0.741 \\
0.678 \\
0.372 \\
0.577 \\
0.345\end{array}$ & $\begin{array}{l}0.061 \\
0.161 \\
0.108 \\
0.171 \\
0.032\end{array}$ & $\begin{array}{l}\text { Preeclampsia } \\
\text { Phosphorus excreted } \\
\quad=53.2 \times \text { Volume }\end{array}$ & & & & \\
\hline
\end{tabular}

* Simultaneous creatinine clearances (see Table I).

of the apparent plasma creatinine was not really creatinine, though the use of the specific enzyme would seem to preclude this possibility.

From this we may tentatively assume that the endogenous creatinine clearance, as done in the present study, measures glomerular filtration in man, at least roughly.

The quantitative dependence of the plasma creatinine clearance upon the final urine volume (or perhaps the converse), at levels below about 0.5 $\mathrm{ml}$. per minute, is shown in Figure 1. On the assumption that the clearance measures glomerular filtration, it must be concluded that in oliguria the final urine volume varies directly with the filtration. Several investigators have shown that at all ordinary volumes, above $0.6 \mathrm{ml}$. per minute, the filtration rate is essentially constant in man. The urine volume, which may vary enormously, is regulated entirely by the tubular reabsorption of water (7). Even markedly reduced glomerular filtration, on the other hand, does not usually result in a diminished output, since there is characteristically a polyuria in advanced chronic nephritis.

However, the findings on excretion at low urine volumes, reported here, suggest that at minimal levels the amounts of fluid filtered by the glomeruli do influence the quantity of final urine. The excretion of all the substances investigated varies directly with the urine volume, in the minimal range. The simplest possible explanation for this would be that varying amounts are filtered. 
It is only at these minimal urine volumes that the amounts excreted do vary directly with the quantity of urine, and therefore it is only in this range of volumes that the final amount of urine bears any definite relation to the amount of fluid filtered by the glomeruli. Chasis $(7,13)$ found that the inulin clearance showed no decrease, in man, as the urine volume fell to as low as $0.6 \mathrm{ml}$. per minute. This is roughly confirmed by some of the data in Table I; when the urine volume is above 0.4 to $0.5 \mathrm{ml}$. per minute, the endogenous creatinine clearance is practically constant. It is only below this level that the clearance shows the linear decrease to zero, as the urine volume falls.

When the minute volume of urine falls to 0.35 to $0.5 \mathrm{ml}$., the concentrations of all substances studied reach their highest levels. Further decrease in volume is without effect upon the concentrations, which appear to be maximal for the existing conditions. Relative to the amounts of the different solids excreted, there is a constant and perhaps maximal amount of water reabsorbed at all urine volumes below the critical level. Perhaps this means that the kidneys are doing a maximal amount of osmotic work, and further reabsorption of water is impossible without further reabsorption of solids.

Assuming for the moment that there is a maximal tubular reabsorption of water when the urine volume falls to $0.4 \mathrm{ml}$. per minute, and that the glomerular filtrate is $120 \mathrm{ml}$. per minute (7), it is seen that the tubules have reabsorbed $119.6 \mathrm{ml}$. of water per minute, or 99.67 per cent of the filtered volume.

There is a possible alternative explanation of the findings which have been interpreted as meaning a decreasing glomerular filtration. Perhaps the glomerular filtration is still constant in this range of minimal urine volumes, but the tubules reabsorb water and each of the several excretory products in exact proportion as the volume falls below the critical level. The kidney must, then, deal with each substance separately, yet in quantitatively the same manner, so that the proportion of any one substance to water, and to every other substance is fixed. This reabsorption must include creatinine, which has never been shown to be reabsorbed, nor even considered to be.

In the lower animals, the urine volume is apparently controlled primarily by glomerular fil- tration. In fact, the glomerulus, in the course of evolution, seems to have been developed in response to a need for excreting water (8). This control of the urine volume by glomerular filtration has been demonstrated in the frog by Marshall (9), and in the sculpin by Clarke (10). In the mammals, glomerular filtration, thanks to a coincidentally efficient tubular reabsorption of water and certain other substances, has been secondarily diverted to excretion of wastes. And in most mammals, there seems to be no relation between glomerular filtration and final urine volume, at ordinary levels. For the rabbit, Kaplan and Smith (11) did find that the clearances of inulin and creatinine "vary with the urine flow; in fact, these clearances fall precipitously at urine flows below $1 \mathrm{cc}$. per square meter per minute" and "... the present data on the excretion of inulin and creatinine point very strongly to a physiological association between glomerular function and urine flow in the rabbit." Perhaps this statement also applies for the human kidney, though only when the urine volume is very low. When the tubules have reached their peak capacity in reabsorbing water, the glomeruli may revert to their primitive function in conserving water by decreasing filtration.

Since the trend of creatinine clearances shown in Figure 1 extrapolates back to zero, it follows that at very small urine volumes the glomerular filtration becomes very small. The question arises as to what may be the mechanism regulating the filtration. Renal ischemia is a possibility reviewed by Kaplan and Smith (11) in discussing variations in glomerular filtration in the rabbit. Another possibility lies in the differential contraction of the afferent and efferent glomerular vessels, which would produce changes in glomerular pressure. Changes in glomerular pressure probably do occur on this basis; the literature is reviewed by Winton (12). Whatever the mechanism, there is the further question as to the nature of the stimulus eliciting the changes in glomerular filtration.

\section{SUMMARY AND CONCLUSIONS}

When the urine volume falls below a critical limit of about 0.35 to $0.5 \mathrm{ml}$. per minute (21 to $30 \mathrm{ml}$. per hour, 504 to $720 \mathrm{ml}$. per 24 hours) urea, creatinine, inorganic phosphorus, total ni- 
trogen, total non-nitrogenous solids, and total solids become maximally concentrated. Further reduction in urine volume does not increase the concentration.

The plasma clearance of endogenous creatinine, as well as the excretion of the other substances studied, shows a quantitative linear dependence upon the urine volume, in the minimal range. It is therefore suggested that these urine volumes vary with glomerular filtration. This implies that a constant and perhaps maximal proportion of the filtered water is reabsorbed by the tubules.

I am indebted to Dr. S. A. Cosgrove for his interest in this work, and for the use of his private as well as ward patients.

\section{BIBLIOGRAPHY}

1. Chesley, L. C., The validity of the calculation of standard urea clearances from low urine volumes. J. Clin. Invest., 1937, 16, 653.

2. Chesley, L. C., Urea excretion at low urine volumes. The calculation of "minimal" urea clearances. J. Clin. Invest., 1938, 17, 119.

3. Hawk, P. B., and Bergeim, O., Practical Physiological Chemistry. Blakiston's Sons, Philadelphia, 1931, 10th ed., pp. $421,813,835,876$.
4. Peters, J. P., and Van Slyke, D. D., Quantitative Clinical Chemistry. Vol. II. Methods. Williams and Wilkins Co., Baltimore, 1932, p. 527.

5. Miller, B. F., and Winkler, A. W., The renal excretion of endogenous creatinine in man. Comparison with exogenous creatinine and inulin. $\mathrm{J}$. Clin. Invest., 1938, 17, 31.

6. Miller, B. F., and Dubos, R., Studies on the presence of creatinine in human blood. J. Biol. Chem., 1937, 121, 447.

7. Smith, H. W., The Physiology of the Kidney. Oxford University Press, New York, 1937, pp. 64 to 68.

8. Marshall, E. K., Jr., The comparative physiology of the kidney in relation to theories of renal secretion. Physiol. Rev., 1934, 14, 133.

9. Marshall, E. K., Jr., The secretion of urea in the frog. J. Cell. and Comp. Physiol., 1932, 2, 349.

10. Clarke, R. W., The xylose clearance of Myoxocephalus octodecimspinosus under normal and diuretic conditions. J. Cell. and Comp. Physiol., 1934, 5, 73.

11. Kaplan, B. I., and Smith, H. W., Excretion of inulin, creatinine, xylose and urea in the normal rabbit. Am. J. Physiol., 1935, 113, 354.

12. Winton, F. R., Physical factors involved in the activities of the mammalian kidney. Physiol. Rev., 1937, 17, 408.

13. Chasis, H., Unpublished data. 